\title{
Catalytic Oxidation of Nitric Oxide to Nitrogen Dioxide on Ru-FAU
}

\author{
Lingling Qu $\cdot$ Jinjun Li $\cdot$ Zhengping Hao \\ Landong $\mathrm{Li}$
}

Received: 13 March 2009/ Accepted: 27 March 2009/Published online: 27 May 2009

(C) Springer Science+Business Media, LLC 2009

\begin{abstract}
Ru-FAU samples were prepared by wet impregnation and studied as promising catalysts for $\mathrm{NO}$ oxidation. The existence of rare earth ions in FAU structure showed positive effect on $\mathrm{NO}$ oxidation while the existence of alkali metal ions on cation sites showed negative effect. As a result, Ru-REY exhibited the best activity and a maximal NO conversion of ca. 94\% was obtained at $250{ }^{\circ} \mathrm{C}$ at a very high WHSV of $180,000 \mathrm{~h}^{-1}$.
\end{abstract}

Keywords NO oxidation - Ru catalysts - FAU zeolite · REY

\section{Introduction}

Nitrogen oxides are known to be associated with several environmental and health hazards, including photochemical smog and acid rain. Due to the increasingly stringent regulations on nitrogen oxide emissions, various posttreatment methods have been attempted for the reduction of $\mathrm{NO}_{x}$ emissions in excess oxygen [1]. In the case of stationary sources, the selective catalytic reduction of $\mathrm{NO}_{x}$ by ammonia $\left(\mathrm{NH}_{3}\right.$-SCR), a state-of-the-art technology for $\mathrm{NO}_{x}$ abatement, has been extensively studied. In the case of mobile sources, the selective catalytic reduction of $\mathrm{NO}_{x}$ by hydrocarbons (HC-SCR) and $\mathrm{NO}_{x}$ storage and reduction

\footnotetext{
L. Qu $\cdot$ J. Li $\cdot$ Z. Hao $\cdot$ L. Li ( $ه)$

Research Center for Eco-Environmental Sciences,

Chinese Academy of Sciences, 100085 Beijing,

People's Republic of China

e-mail: lilandong@rcees.ac.cn

L. Qu

China University of Mining \& Technology (Beijing),

100083 Beijing, People's Republic of China
}

(NSR) are two major techniques and draw much attention. During the above-mentioned processes, it becomes more and more evident now that $\mathrm{NO}_{2}$ plays a decisive role. For $\mathrm{NO}_{x}$ storage and reduction, $\mathrm{NO}$ is first oxidized to $\mathrm{NO}_{2}$ over the noble metal component and then stored as nitrates or nitrites on the basic component [2]. For the selective catalytic reduction of $\mathrm{NO}_{x}, \mathrm{NO}$ is partially oxidized to $\mathrm{NO}_{2}$, which subsequently reacts with hydrocarbon or $\mathrm{NH}_{3}$ to give out $\mathrm{N}_{2}$ [3]. More important, the so-called "fast" SCR reaction $\left(4 \mathrm{NH}_{3}+2 \mathrm{NO}+2 \mathrm{NO}_{2} \rightarrow 4 \mathrm{~N}_{2}+6 \mathrm{H}_{2} \mathrm{O}\right)$, in contrast to standard ammonia $\mathrm{SCR}$ reaction $\left(4 \mathrm{NH}_{3}+\right.$ $4 \mathrm{NO}+\mathrm{O}_{2} \rightarrow 4 \mathrm{~N}_{2}+6 \mathrm{H}_{2} \mathrm{O}$ ), is drawing more and more attention in recent years [4-8]. The reaction between equimolar $\mathrm{NO}-\mathrm{NO}_{2}$ and $\mathrm{NH}_{3}$ is ca. 10 times faster than the reaction between $\mathrm{NO}$ and $\mathrm{NH}_{3}$ at low temperatures (200$300{ }^{\circ} \mathrm{C}$ ). Therefore, the fast SCR reaction is considered as a feasible means to boosting the denitrification efficiency at lower temperatures as well as to reducing the catalyst costs of SCR system. However, it is known that nitrogen oxides produced from emission sources mainly consist of $\mathrm{NO}$ $(>90 \%)$. Thus, the oxidation of $\mathrm{NO}$ to $\mathrm{NO}_{2}$ becomes a key step to realize the fast SCR process and catalysts with sufficient activity for NO oxidation are being researched.

During the research of NO oxidation catalysts, supported platinum catalysts drew much attention. $\mathrm{Pt} / \mathrm{SiO}_{2}$ $[9,10]$ and $\mathrm{Pt} / \mathrm{Al}_{2} \mathrm{O}_{3}[11,12]$ have been reported to be highly active for $\mathrm{NO}$ oxidation, and up to now supported platinum catalysts are still regarded as model catalysts for NO oxidation. As for supported platinum catalysts, the deactivation in strong oxidizing conditions remains a big problem to be solved [13]. Moreover, the high cost of noble metal platinum materials also restricts the application of supported Pt catalysts to a great extent. Therefore, alternative catalysts for NO oxidation are under investigation. For example, supported cobalt catalysts have been 
reported to be very active for NO oxidation by several groups [14-16].

In this work, less expensive ruthenium is selected as the alternative active component for NO oxidation and zeolites with FAU structure are employed as catalytic supports. RuFAU samples are prepared by simple impregnation and tested as promising catalysts for NO oxidation. The effects of zeolite supports choice, optimal ruthenium loading and experimental conditions on NO oxidation activity are discussed in details.

\section{Experimental}

\subsection{Catalysts Preparation}

Commercial zeolites with FAU structure, NaY $(\mathrm{Si} / \mathrm{Al}=$ 3.8), HY ( $\mathrm{Si} / \mathrm{Al}=5.4)$, ultra-stable Y (USY, Si/Al = 11.6) and rare earths $\mathrm{Y}\left(\mathrm{REY}, \mathrm{Si} / \mathrm{Al}=7.2, \mathrm{RE}_{2} \mathrm{O}_{3} \mathrm{wt} \%=5.2\right)$ were provided by Sinopec. Co and directly used as catalyst supports. Ruthenium species were introduced to the support by wet impregnation using $\mathrm{RuCl}_{3}$ as precursor. In a typical synthesis, $1 \mathrm{~g}$ zeolite support was impregnated with a certain amount of $2 \mathrm{mM} \mathrm{RuCl}{ }_{3}$ aqueous solution under vigorous stirring at a constant temperature of $80{ }^{\circ} \mathrm{C}$. The as-prepared samples were dried at $100{ }^{\circ} \mathrm{C}$ over night and then calcined at $450{ }^{\circ} \mathrm{C}$ in flowing air for $4 \mathrm{~h}$.

For reference, $\mathrm{Ru} / \mathrm{TiO}_{2}$ with $\mathrm{Ru}$ weight loading of ca. $2 \%$ and $\mathrm{Pt} / \mathrm{Al}_{2} \mathrm{O}_{3}$ with $\mathrm{Pt}$ weight loading of ca. $2 \%$ were also prepared by similar wet impregnation process.

\subsection{Catalyst Characterization}

The Ru, Si and Al loadings in Ru-FAU samples were determined by ICP-AES using an Optima 2000 spectrometer.

The surface areas of Ru-FAU catalysts were analyzed by low temperature $\mathrm{N}_{2}$ adsorption/desorption using a Quantachrome NOVA-1200 gas absorption analyzer and the specific surface areas were calculated using the BET equation.

The dispersion of ruthenium on FAU support was determined by $\mathrm{CO}$ pulse adsorption on a chemisorption analyzer (Chemisorb 2720, Micromeritics). In a typical experiment, ca. $100 \mathrm{mg}$ sample in the quartz reactor was first reduced in $5 \% \mathrm{H}_{2} / \mathrm{He}$ at $450{ }^{\circ} \mathrm{C}$ for $1 \mathrm{~h}$ and pre-treated in $\mathrm{He}$ at $450{ }^{\circ} \mathrm{C}$ for $1 \mathrm{~h}$ to remove $\mathrm{H}_{2}$ adsorbed on the surface of samples. After cooling down to room temperature in flowing $\mathrm{He}$, pulses of $5 \% \mathrm{CO} / \mathrm{He}$ were injected to the reactor one pulse per minute until no further changes in signal intensity of outlet CO. The dispersion of ruthenium was calculated assuming the equimolar adsorption of $\mathrm{CO}$ on ruthenium metal.

The X-ray diffraction patterns of samples were recorded on a Rigaku powder diffractometer (D/MAX-RB) using
$\mathrm{Cu}-\mathrm{K} \alpha$ radiation $(\lambda=0.15418 \mathrm{~nm})$ at a scanning rate of $4 \% \min$ in $2 \theta=5-80^{\circ}$.

The temperature-programmed reduction experiments of samples were carried out on a chemisorption analyzer (Chemisorb 2720, Micromeritics) with 5 vol $\% \mathrm{H}_{2} / \mathrm{Ar}$ at a heating rate of $10{ }^{\circ} \mathrm{C} / \mathrm{min}$ from 50 to $700{ }^{\circ} \mathrm{C}$. Prior to reduction, the sample $(100 \mathrm{mg})$ was treated in $\mathrm{He}$ at $450{ }^{\circ} \mathrm{C}$ for $1 \mathrm{~h}$.

The temperature-programmed desorption of oxygen $\left(\mathrm{O}_{2}\right.$-TPD) were also performed on the chemisorption analyzer. The samples were pre-treated in 5 vol $\% \mathrm{O}_{2} / \mathrm{He}$ at $450{ }^{\circ} \mathrm{C}$ for $1 \mathrm{~h}$ and then cooled down to room temperature in the same flow. After He purge for $30 \mathrm{~min}$ at $50{ }^{\circ} \mathrm{C}$, the temperature-programmed desorption experiments were conducted in He flow from 50 to $700{ }^{\circ} \mathrm{C}$ at a heating rate of $10{ }^{\circ} \mathrm{C} / \mathrm{min}$.

Transmission electron microscopy images of samples were acquired on a JEOL 3010 transmission electron microscope at an acceleration voltage of $200 \mathrm{kV}$. Samples were crushed and deposited on a carbon-coated copper grid, and then evaporate at room temperature.

\subsection{Catalytic Oxidation of Nitric Oxide}

The catalytic oxidation of NO was carried out in a fixed-bed flow micro reactor at atmospheric pressure. A $0.15 \mathrm{~g}$ sample (sieve fraction of $0.17-0.25 \mathrm{~mm}$, small enough to exclude internal mass transfer limitations) was placed in a quartz reactor $\left(4 \mathrm{~mm}\right.$ i.d.) and pretreated in $5 \% \mathrm{O}_{2} / \mathrm{He}$ at $450{ }^{\circ} \mathrm{C}$ for $1 \mathrm{~h}$. After cooling to $150{ }^{\circ} \mathrm{C}$ in $\mathrm{He}$, the reactant gas was fed to the reactor. A typical reactant gas composition was $400 \mathrm{ppm}$ $\mathrm{NO}, 10 \% \mathrm{O}_{2}$, and balance He. The total flow rate of the gas mixture was maintained at $450 \mathrm{~mL} \mathrm{~min}^{-1}$, corresponding to a WHSV of $180,000 \mathrm{~mL} / \mathrm{g}_{\mathrm{cat}} \mathrm{h}$. The inlet and outlet gases were monitored on-line using a gas chromatograph (HP 6820 series, for $\mathrm{N}_{2}$ and $\mathrm{N}_{2} \mathrm{O}$ analysis) and a chemiluminescence $\mathrm{NO}_{x}$ analyzer (Ecotech EC 9841, for NO and $\mathrm{NO}_{2}$ analysis).

\section{Results and Discussion}

\subsection{Characterization Results of Ru-FAU Samples}

The physical properties of as-prepared Ru-FAU samples are characterized and the results are summarized in Table 1. It is seen that the $\mathrm{Si} / \mathrm{Al}$ ratios in each samples increase to some degree in comparison with parent zeolite, indicating the dealumination (up to $10 \%$ ) during preparation process. Besides, the surface areas of Ru-FAU are observed to be in the range of $400-550 \mathrm{~m}^{2}$ and the dispersion of ruthenium on different zeolites is found to be $40-60 \%$. 
Table 1 Physical properties of Ru-FAU samples

\begin{tabular}{llcll}
\hline Catalyst & $\begin{array}{l}\text { Ru loading } \\
(\mathrm{wt} \%)\end{array}$ & Si/Al & $\begin{array}{l}\text { Surface } \\
\text { area }\left(\mathrm{m}^{2} / \mathrm{g}\right)\end{array}$ & $\begin{array}{l}\text { Ru dispersion } \\
(\%)\end{array}$ \\
\hline Ru-NaY & 1.93 & 4.3 & 447.8 & 49.5 \\
Ru-HY & 1.98 & 5.9 & 548.1 & 52.3 \\
Ru-USY & 1.95 & 13.1 & 537.4 & 55.2 \\
Ru-ReY & 1.91 & 7.5 & 431.2 & 54.7 \\
Ru-REY-0.5\% & 0.54 & 7.9 & 445.2 & 59.2 \\
Ru-REY-1\% & 0.97 & 7.4 & 439.4 & 56.5 \\
Ru-REY-4\% & 3.85 & 8.1 & 419.8 & 40.8 \\
\hline
\end{tabular}

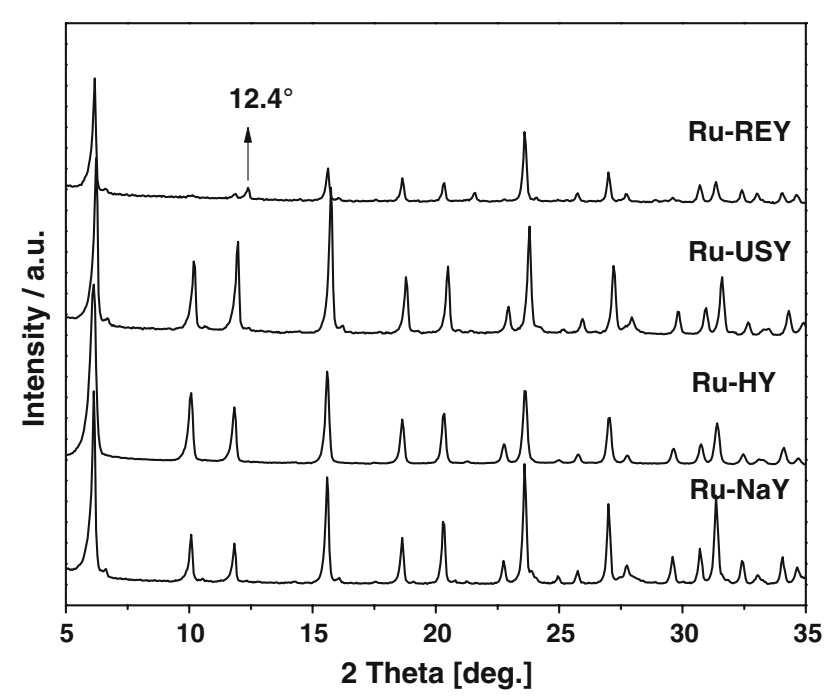

Fig. 1 XRD patterns of various Ru-FAU samples

Figure 1 shows XRD patterns of various Ru-FAU catalysts. It is seen that Ru-NaY, Ru-HY and Ru-USY show almost identical diffraction lines, corresponding to the typical structure of FAU zeolites [17]. As for Ru-REY, the intensities of all diffraction lines corresponding to FAU structure decrease to some extent and especially the two diffraction lines at $10.3^{\circ}$ and $12.0^{\circ}$ almost disappear. It is thus indicated the introduction of rare earths to FAU zeolite may result in the partial destruction of zeolite structure. Besides, a weak diffraction line at $12.4^{\circ}$ is also observed in the XRD pattern of Ru-REY, corresponding to the rare earth ions inside the super cages [18]. Generally, rare earth ions may be located both inside the super cages and inside the sodality cages of REY. In this work, the diffraction line at $12.4^{\circ}$ corresponding to rare ions inside the super cages is clearly observed and the diffraction line at $11.8^{\circ}$ corresponding to rare ions inside the sodalite cages is very weak. Therefore, we believe that most rare earth ions are located inside the super cages of REY. For all Ru-FAU samples, no diffraction lines corresponding to ruthenium oxides are observed, which can be ascribed to the poor crystallization or good dispersion of ruthenium oxides.

The $\mathrm{H}_{2}$-TPR profiles of Ru-FAU samples are shown in Fig. 2. The reduction peaks at below $250{ }^{\circ} \mathrm{C}$ should be ascribed to the reduction of different types of Ru oxides since the support materials cannot be reduced within this temperature range. For Ru-USY, two reduction peaks at $100{ }^{\circ} \mathrm{C}$ and $130{ }^{\circ} \mathrm{C}$ are observed, which can be ascribed to the reduction of highly dispersed amorphous $\mathrm{RuO}_{2}$ and bulk amorphous $\mathrm{RuO}_{2}[19,20]$, respectively. As for Ru$\mathrm{NaY}$, the reduction of highly dispersed amorphous $\mathrm{RuO}_{2}$ and bulk amorphous are observed at higher temperature than that on Ru-USY, e.g., at $120^{\circ} \mathrm{C}$ and $155{ }^{\circ} \mathrm{C}$, respectively. The existence of alkali metal ions $\mathrm{Na}^{+}$in FAU structure significantly retards the reduction of ruthenium oxides by hydrogen, consistent with literature results [21]. As for Ru-REY, a reduction peak at ca. $70{ }^{\circ} \mathrm{C}$ is observed and ascribed to the reduction of amorphous ruthenium oxides. It is noted that the reduction temperature of amorphous ruthenium oxides on Ru-REY is much lower than that on Ru-USY, probable due to the interaction between ruthenium oxides and rare earth ions. Besides, two reduction peaks at $580{ }^{\circ} \mathrm{C}$ and $610{ }^{\circ} \mathrm{C}$ corresponding to the reduction of rare earth ions are observed on Ru-REY.

The $\mathrm{H}_{2}$ consumption during the reduction of ruthenium species (reduction peaks at below $250{ }^{\circ} \mathrm{C}$ ) in Ru-FAU is calculated and displayed in Fig. 2. The $\mathrm{H}_{2}$ consumption indicates that most ruthenium species exist in the state of $\mathrm{Ru}^{4+}$, i.e., $\mathrm{RuO}_{2}$ and are reduced to metallic $\mathrm{Ru}$ during TPR process. From the $\mathrm{H}_{2}$-TPR profiles of Ru-FAU samples, following two aspects can be easily concluded. Firstly, ruthenium species exist in Ru-FAU in the form of amorphous $\mathrm{RuO}_{2}$ that can be reduced at below $200{ }^{\circ} \mathrm{C}$. Secondly, the alkali metal ions $\mathrm{Na}^{+}$in FAU structure retard the reduction of ruthenium species by hydrogen while the rare earth ions promote the reduction of ruthenium species by hydrogen in Ru-FAU.

The $\mathrm{O}_{2}$-TPD profiles of the Ru-FAU samples are shown in Fig. 3. In the temperature range of $100-300{ }^{\circ} \mathrm{C}$, there are two desorption peaks over each sample. These peaks are ascribed to the desorption of surface oxygen species, the peak at lower temperature to $\mathrm{O}^{2-}$ and the peak at higher temperature to $\mathrm{O}^{-}[22,23]$. It is seen that the desorption of surface oxygen is facilitated by the existence of rare earth ions while it is retarded by the existence of alkali metal ions, considering the temperature difference for surface 


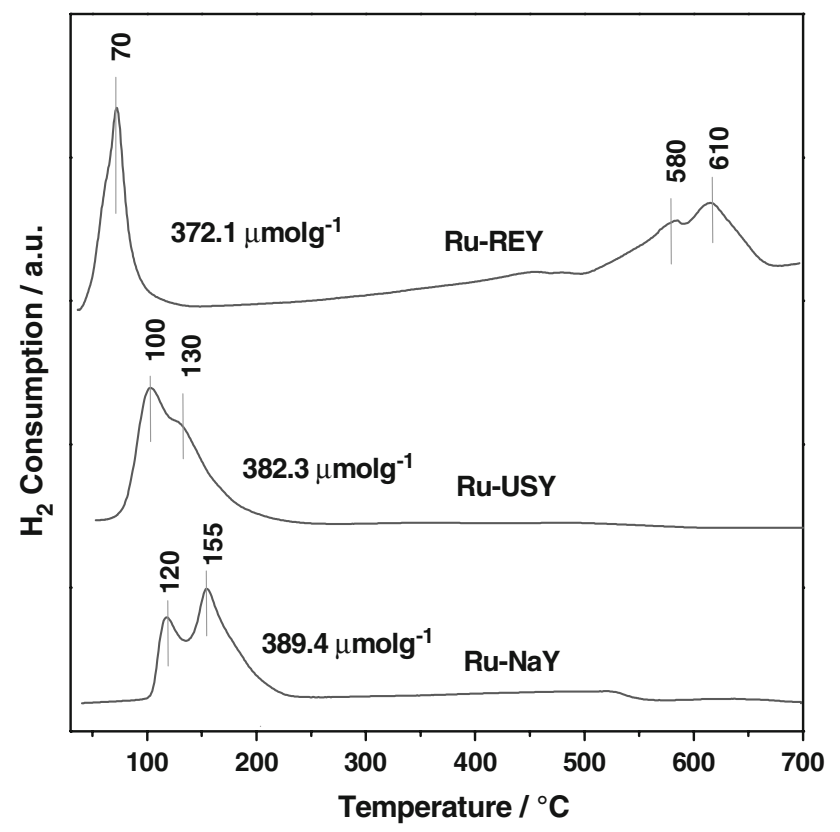

Fig. $2 \mathrm{H}_{2}$-TPR profiles of various Ru-FAU samples

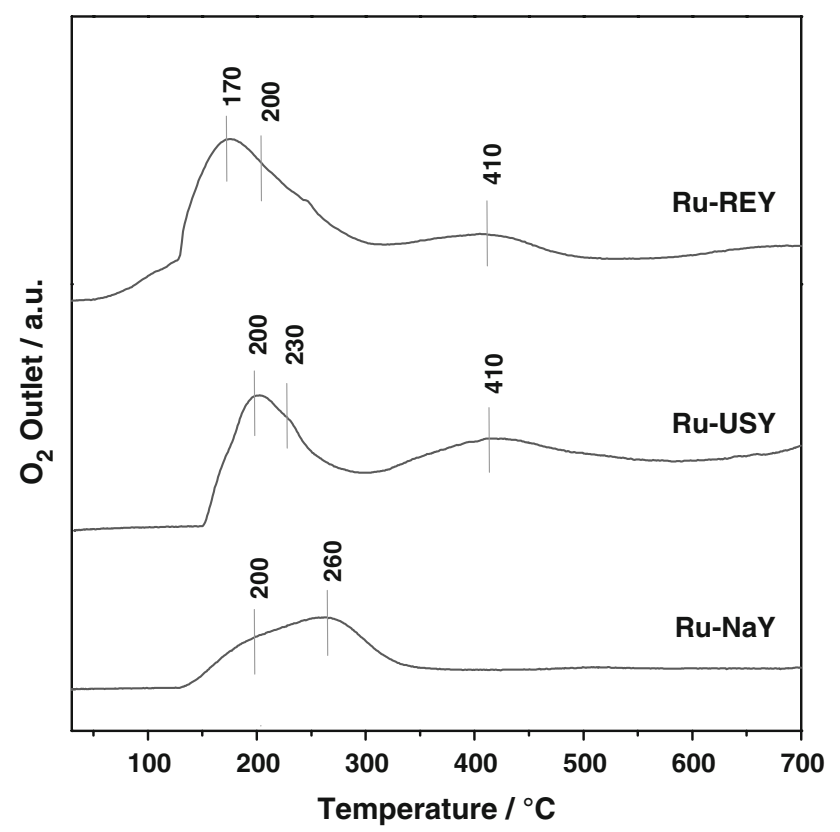

Fig. $3 \mathrm{O}_{2}$-TPD profiles of various Ru-FAU samples

oxygen desorption. On Ru-REY and Ru-USY, an oxygen desorption peak at high temperature of ca. $410{ }^{\circ} \mathrm{C}$ is observed, which should be ascribed to the desorption of lattice oxygen from ruthenium oxides. There are no similar peaks observed on $\mathrm{Ru}-\mathrm{NaY}$, due to the interaction between $\mathrm{Na}^{+}$and ruthenium oxides. The $\mathrm{O}_{2}$-TPD results in this work are employed to illustrate the interaction between ruthenium oxides and rare earth ions or alkali metal ions in Ru-FAU.

\subsection{NO Oxidation Over Ru-FAU Catalysts}

The temperature dependence of steady-state NO oxidation over $\mathrm{Ru}-\mathrm{FAU}, \mathrm{Ru} / \mathrm{TiO}_{2}$ and $\mathrm{Pt} / \mathrm{Al}_{2} \mathrm{O}_{3}$ are shown in Fig. 4. For reference, the thermodynamic equilibrium for NO- $\mathrm{NO}_{2}$ under given conditions is also shown in the figure (in dashed). The main product for NO oxidation is $\mathrm{NO}_{2}$, and the formation of other $\mathrm{N}$-containing product, such as $\mathrm{N}_{2} \mathrm{O}$ and $\mathrm{N}_{2}$, can be neglected. The NO conversion to $\mathrm{NO}_{2}$ over catalysts was kinetically limited at low temperatures and equilibrium limited at higher temperatures. For Ru-FAU catalysts, Ru-REY shows the highest activity, followed by Ru-HY and Ru-USY, and then Ru$\mathrm{NaY}$. For the best Ru-REY catalyst, a 50\% NO conversion to $\mathrm{NO}_{2}$ was achieved at ca. $230^{\circ} \mathrm{C}$ and the maximal $\mathrm{NO}$ conversion of ca. $94.5 \%$ is achieved at ca. $250{ }^{\circ} \mathrm{C}$. At above $250{ }^{\circ} \mathrm{C}$, the $\mathrm{NO}$ conversion dropped gradually along the thermodynamic equilibrium. It should be noted that the NO oxidation activity of Ru-REY is obtained at a very high WHSV of $180,000 \mathrm{~mL} / \mathrm{g}_{\text {cat }} \mathrm{h}$ and the activity is higher than that on other supported ruthenium catalysts, e.g., $\mathrm{Ru}-\mathrm{TiO}_{2}$ [20]. The activity of $\mathrm{Ru}-\mathrm{REY}$ is also much higher than that on $\mathrm{Pt} / \mathrm{Al}_{2} \mathrm{O}_{3}$ model catalyst (pre-reduced) for NO oxidation under similar conditions, as shown in Fig. 4. Ru-HY and Ru-USY exhibit similar activity for NO oxidation despite of the different $\mathrm{Si} / \mathrm{Al}$ ratios of $\mathrm{HY}$ and USY. It is thus deduced that the $\mathrm{Si} / \mathrm{Al}$ ratios of FAU zeolites is not a key factor controlling the NO oxidation activity of Ru-FAU catalysts. From the catalytic results, we clearly see that the existence of rare earth ions shows positive effect on NO oxidation while the existence of alkali metal ions on cation sites shows negative effect.

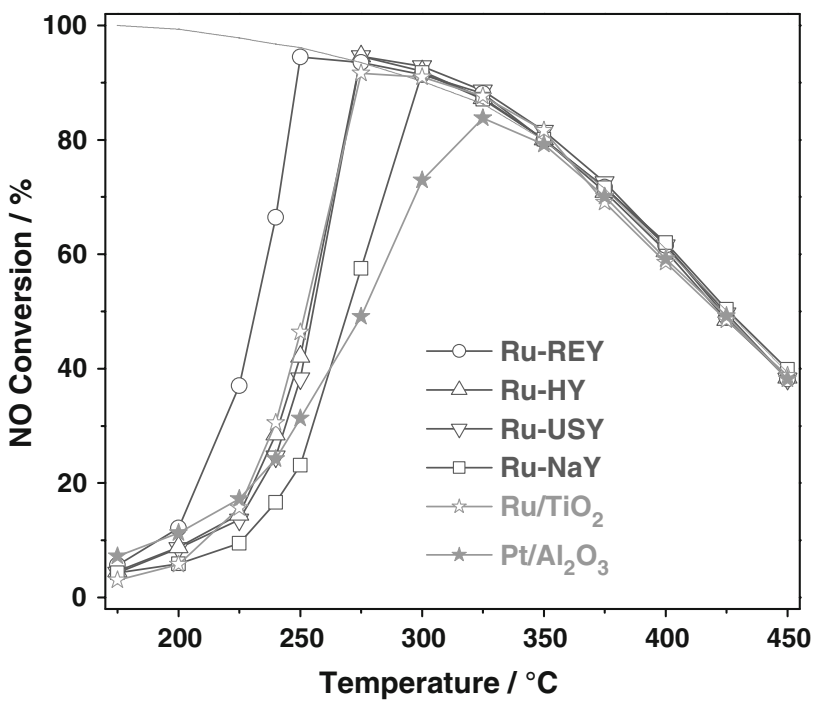

Fig. 4 Catalytic activities for $\mathrm{NO}$ oxidation on $\mathrm{Ru}-\mathrm{FAU}, \mathrm{Ru} / \mathrm{TiO}_{2}$ and $\mathrm{Pt} / \mathrm{Al}_{2} \mathrm{O}_{3}$. Reaction conditions: $0.15 \mathrm{~g}$ catalyst, $400 \mathrm{ppm} \mathrm{NO}$, $10 \% \mathrm{O}_{2}$ and the balance $\mathrm{He}$, WHSV $=180,000 \mathrm{~mL} / \mathrm{g}_{\mathrm{cat}} \mathrm{h}$ 
The nature of ruthenium species is changed by interaction with rare earth ions or alkali metal ions, as indicated by the $\mathrm{H}_{2}$-TPR and $\mathrm{O}_{2}$-TPD results. Correlating the catalytic results and $\mathrm{H}_{2}$-TPR results, it is found that ruthenium oxides reducible at lower temperatures shows higher activity for NO oxidation.

\subsection{Effects of Initial $\mathrm{NO}$ and $\mathrm{O}_{2}$ Concentration on NO Oxidation}

The effects of initial $\mathrm{NO}$ and $\mathrm{O}_{2}$ concentration on $\mathrm{NO}$ oxidation are investigated and the results are displayed in Fig. 5. It is seen that $\mathrm{NO}$ conversion to $\mathrm{NO}_{2}$ slightly decreases from ca. $46 \%$ to ca. $30 \%$ with initial NO concentration increasing from 100 to $1,000 \mathrm{ppm}$ at the constant temperature of $225{ }^{\circ} \mathrm{C}\left(\mathrm{O}_{2}\right.$ concentration fixed at $10 \%)$. The NO conversion increases from ca. $15 \%$ to ca. $38 \%$ with increasing oxygen concentration from 1 to $10 \%$ at $225{ }^{\circ} \mathrm{C}$ with fixed $\mathrm{NO}$ concentration of $400 \mathrm{ppm}$. Further increase in oxygen concentration to $20 \%$ does not bring corresponding increase in $\mathrm{NO}$ conversion as expected. It is evident that oxygen plays a distinct positive role on NO oxidation for $\mathrm{O}_{2}<10 \%$.

\subsection{Effects of $\mathrm{H}_{2} \mathrm{O}$ and $\mathrm{SO}_{2}$ on $\mathrm{NO}$ Oxidation Over Ru-REY}

For practical application, Ru-REY catalysts are expected to work under the conditions with $\mathrm{SO}_{2}$ and water vapor in the stream. So, it is necessary to clarify their effects on NO

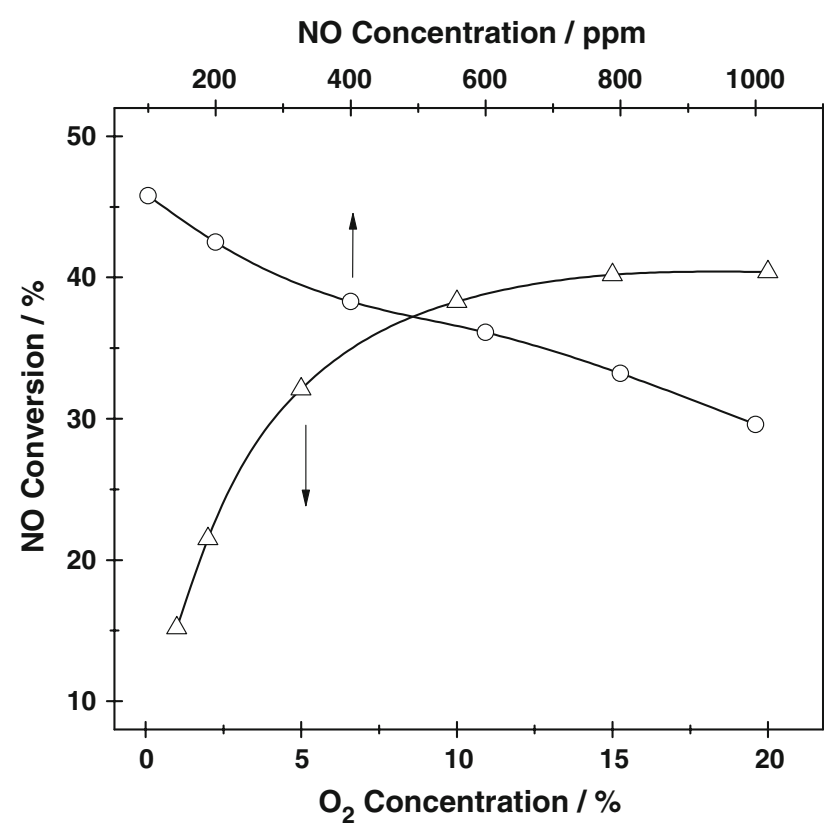

Fig. 5 Influence of initial $\mathrm{NO}$ and $\mathrm{O}_{2}$ concentration on $\mathrm{NO}$ conversion at $225^{\circ} \mathrm{C}$. Reaction conditions: $0.15 \mathrm{~g}$ catalyst, $100-1,000 \mathrm{ppm}$ $\mathrm{NO}, 1-20 \% \mathrm{O}_{2}$ and the balance He, WHSV $=180,000 \mathrm{~mL} / \mathrm{g}_{\text {cat }} \mathrm{h}$

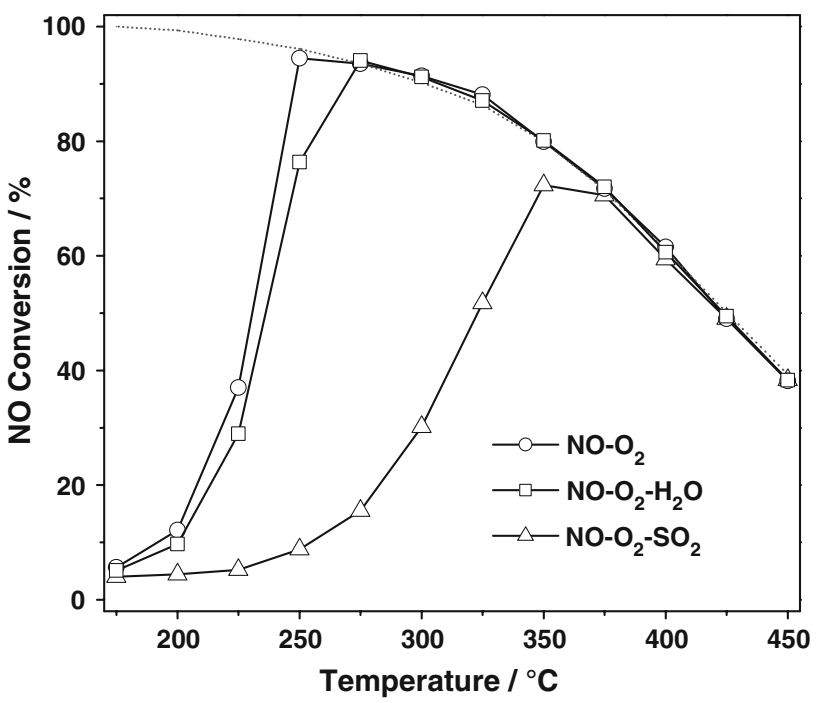

Fig. 6 Influence of $\mathrm{H}_{2} \mathrm{O}$ and $\mathrm{SO}_{2}$ in the stream on $\mathrm{NO}$ conversion over Ru-REY. Reaction conditions: $0.15 \mathrm{~g}$ catalyst, $400 \mathrm{ppm} \mathrm{NO}$, $10 \% \mathrm{O}_{2} 0$ or $2 \% \mathrm{H}_{2} \mathrm{O}, 0$ or $40 \mathrm{ppm} \mathrm{SO}_{2}$, and the balance $\mathrm{He}$, $\mathrm{WHSV}=180,000 \mathrm{~mL} / \mathrm{g}_{\mathrm{cat}} \mathrm{h}$

oxidation. As seen in Fig. 6, the presence of $2 \% \mathrm{H}_{2} \mathrm{O}$ in the reaction system shows slight negative effect on $\mathrm{NO}$ oxidation. For example, the light-off-temperatures (when $\mathrm{T}_{50}$ is achieved) slightly increase from 230 to $236{ }^{\circ} \mathrm{C}$. The inhibition effect of $\mathrm{H}_{2} \mathrm{O}$ on $\mathrm{NO}$ oxidation is presumably originated from the competitive adsorption of $\mathrm{H}_{2} \mathrm{O}$ on the active sites. The presence of $40 \mathrm{ppm} \mathrm{SO}_{2}$ shows more serious negative effect on NO oxidation. Typically, the light-offtemperatures increase from 230 to $321{ }^{\circ} \mathrm{C}$ with the addition of $40 \mathrm{ppm} \mathrm{SO}_{2} . \mathrm{SO}_{2}$ poisoning is known as the most serious problem for $\mathrm{NO}$ catalytic oxidation since catalysts preferred to convert $\mathrm{SO}_{2}$ to $\mathrm{SO}_{3}\left(2 \mathrm{SO}_{2}+\mathrm{O}_{2} \rightarrow 2 \mathrm{SO}_{3}\right)$ instead of oxidation of $\mathrm{NO}$. The formed $\mathrm{SO}_{3}$ may not only occupy the active sites for $\mathrm{NO}$ oxidation but also cover the support materials by forming sulfates [9]. It is seen that the inhibition effect of $\mathrm{SO}_{2}$ on NO oxidation over Ru-REY is not as serious as that over some Pt catalysts [24]. A possible explanation is that $\mathrm{Ru}$ is not as active as $\mathrm{Pt}$ for $\mathrm{SO}_{2}$ oxidation.

\subsection{Effects of Ru Loading on NO Oxidation Over Ru-REY}

In order to obtain the effects of Ru loadings on the NO oxidation activity, Ru-REY catalysts with different $\mathrm{Ru}$ loadings are studied and the results are shown in Fig. 7. Higher activity is observed with higher ruthenium loadings, as Ru-REY-4\% > Ru-REY-2\% > Ru-REY-1\% > Ru-REY-0.5\%. The light-off-temperatures increase from 227 to $277{ }^{\circ} \mathrm{C}$ with Ru loadings decrease from 4 to $0.5 \%$. It should be noted that Ru-REY-4\% only exhibited a little higher activity than Ru-REY-2\% and Ru-REY-1\% also exhibited a little higher activity than Ru-REY- $0.5 \%$ 


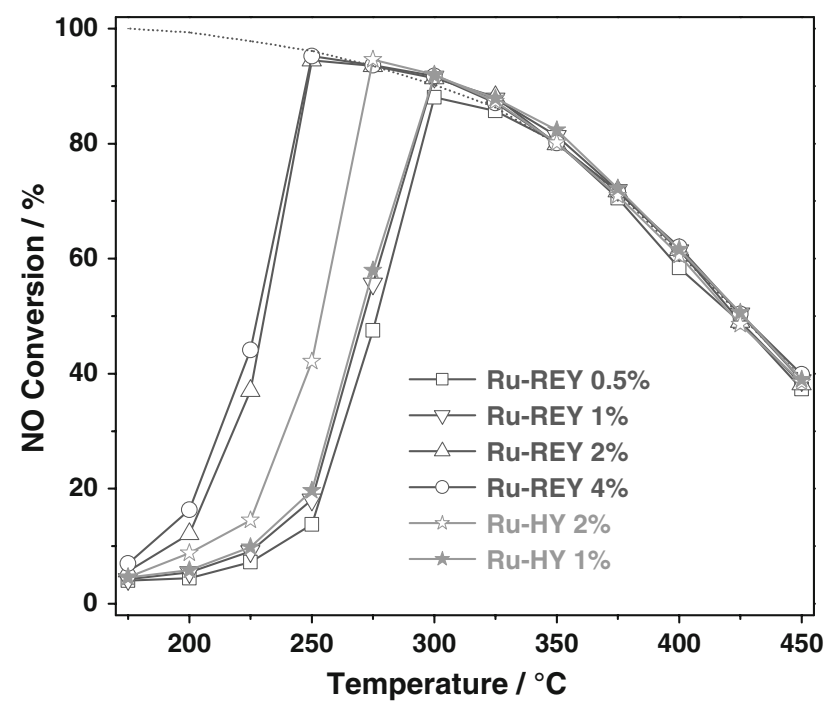

Fig. 7 Catalytic activities for NO oxidation on Ru-REY catalysts with different $\mathrm{Ru}$ loadings. Reaction conditions: $0.15 \mathrm{~g}$ catalyst, $400 \mathrm{ppm} \mathrm{NO}, 10 \% \mathrm{O}_{2}$ and the balance $\mathrm{He}$, WHSV $=$ $180,000 \mathrm{~mL} / \mathrm{g}_{\text {cat }} \mathrm{h}$ though the ruthenium loading was doubled. In contrast, Ru-REY-2\% shows distinct higher activity than Ru-REY$1 \%$. Obviously, NO oxidation activity over Ru-REY is not linearity dependent on ruthenium loadings. By taking both the activity and the cost of catalyst into account, the optimal ruthenium loading is ca. $2 \%$. For reference, the activity of $\mathrm{Ru}-\mathrm{HY}$ with ruthenium loadings of 1 and $2 \%$ are also shown in Fig. 7. It is seen that Ru-HY-1\% exhibits similar activity to Ru-REY-1\% while Ru-HY-2\% exhibits much lower activity than Ru-REY-2\%. A possible explanation is that the promotion effect of rare earth ions on NO oxidation does not operate with ruthenium loading of $1 \%$.

The TEM images of Ru-REY with different ruthenium loadings are shown in Fig. 8. For Ru-REY-0.5\%, no obvious ruthenium oxides can be distinguished, probably due to low ruthenium loading and high dispersion of ruthenium species. For Ru-REY-1\%, very small ruthenium oxides clusters of below $2 \mathrm{~nm}$ can be found after careful observation. In the TEM image of Ru-REY-2\%, ruthenium oxides clusters of 2-4 nm with good dispersion in REY zeolite are clearly
Fig. 8 TEM images of Ru-REY catalysts with different ruthenium loadings
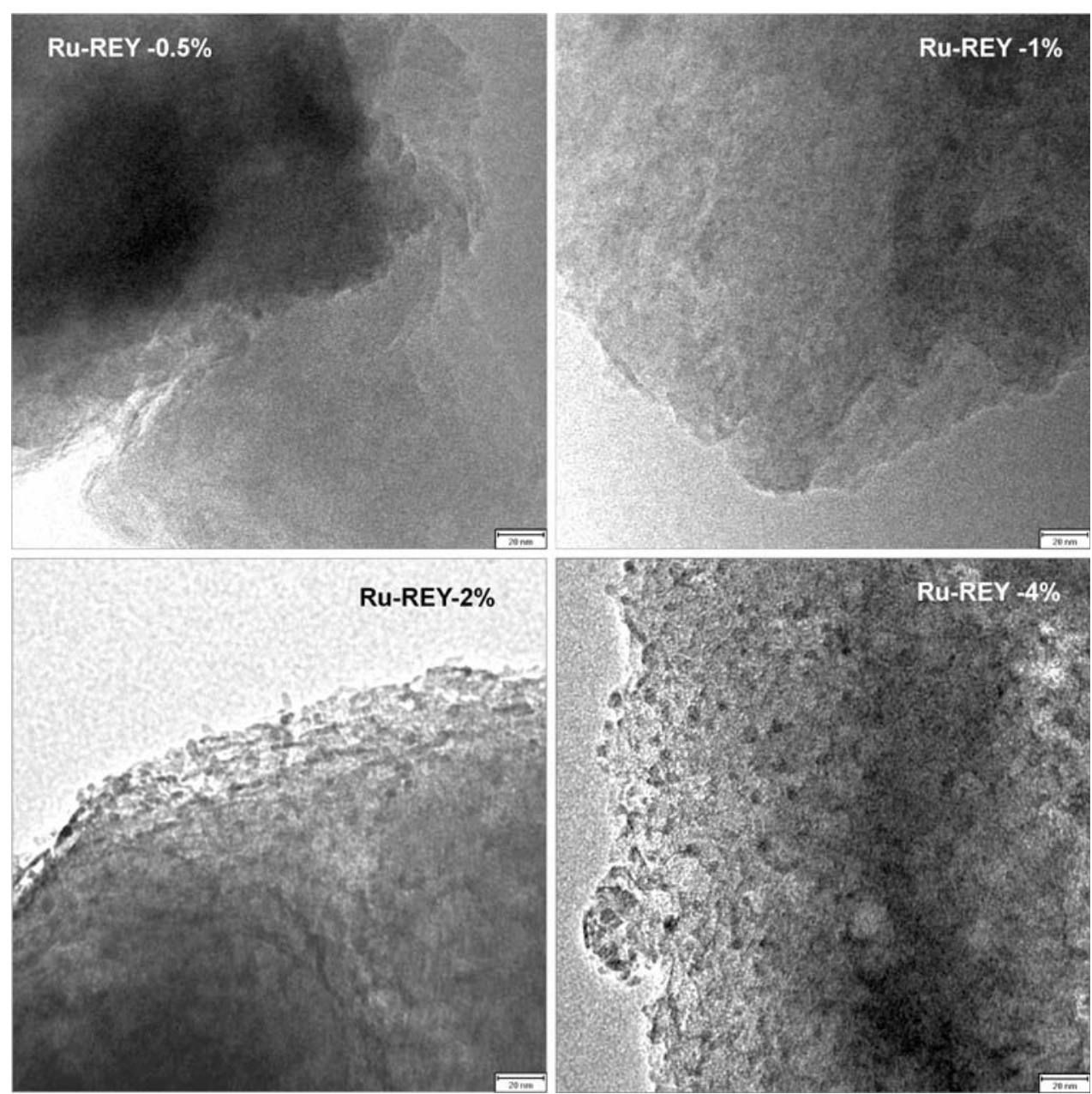
observed. As for Ru-REY-4\%, ruthenium oxides of above $5 \mathrm{~nm}$ are observed. It is easily seen that the size of ruthenium oxides clusters on REY increases with increasing ruthenium loadings.

Compared to that on Ru-REY-2\%, the NO oxidation activity on Ru-REY-0.5\% and Ru-REY-1\% is rather low (see Fig. 7) though ruthenium and rare earth ions both present. It is proposed that the interaction between rare earth ions and ruthenium oxides are formed only if ruthenium loading exceeds a certain value. As for Ru-REY-4\%, much higher NO oxidation activity than Ru-REY-2\% is not obtained as expected though the interaction between rare earth ions and ruthenium oxides are formed and the ruthenium loading is doubled. A possible explanation can be given from the decrease in ruthenium dispersion from 54.7 to $40.8 \%$, as seen in Table 1 .

\section{Conclusion}

Zeolites NaY, HY, USY and REY with the similar FAU structure were employed as catalyst supports and ruthenium was introduced on the supports by simple wet impregnation. The as-prepared Ru-FAU samples were studied as promising catalysts for NO oxidation. Ru-REY exhibited the highest activity for NO oxidation, followed by Ru-HY and Ru-USY and then Ru-NaY. As for Ru-REY catalyst, a maximal NO conversion of ca. $94 \%$ could be obtained at $250{ }^{\circ} \mathrm{C}$ under a very high WHSV of $180,000 \mathrm{~h}^{-1}$. Based on the $\mathrm{H}_{2}$-TPR and $\mathrm{O}_{2}$-TPD results on $\mathrm{Ru}-\mathrm{FAU}$, it is found that both the rare earth ions in REY and alkali metal ions in $\mathrm{NaY}$ could interact with ruthenium oxides and subsequently change the nature of ruthenium oxides on FAU zeolites. As a consequence, rare earth ions show positive effect on NO oxidation over Ru-FAU while alkali metal ions $\mathrm{Na}^{+}$showed negative effect. The optimal ruthenium loading in Ru-REY catalyst for $\mathrm{NO}$ oxidation is determined to be ca. $2 \%$. The presence of $\mathrm{H}_{2} \mathrm{O}$ in reaction system shows mild negative effect on $\mathrm{NO}$ oxidation while the presence of $\mathrm{SO}_{2}$ shows great negative effect on $\mathrm{NO}$ oxidation.
Acknowledgments This work was financially supported by the National Natural Science Foundation of China (20703057, 20725723).

\section{References}

1. Bosch H, Jassen F (1988) Catal Today 2:369-521

2. Epling WS, Campbell LE, Yezerets A, Currier NW, Parks JEII (2004) Catal Rev Sci Eng 46:163-245

3. Burch R (2004) Catal Rev Sci Eng 46:271-333

4. Koebel M, Madia G, Elsener M (2002) Catal Today 73:239-247

5. Nova I, Ciardelli C, Tronconi E, Chatterjee D, Bandl-Konrad B (2006) Catal Today 114:3-12

6. Devadas M, Kröcher O, Elsener M, Wokaun A, Söger N, Pfeifer M, Demel Y, Mussmann L (2006) Appl Catal B 67:187-196

7. Ciardelli C, Nova I, Tronconi E, Chatterjee D, Bandl-Konrad B, Weibel M, Krutzsch B (2007) Appl Catal B 70:80-90

8. Grossale A, Nova I, Tronconi E, Chatterjee D, Weibel M (2008) J Catal 256:312-322

9. Xue E, Seshan K, Ross JRH (1996) Appl Catal B 11:65-79

10. Després J, Elsener M, Koebel M, Kröcher O, Schnyder B, Wokaun A (2004) Appl Catal B 50:73-82

11. Schmitz PJ, Kudla RJ, Drews AR, Chen AE, Lowe-Ma CK, McCabe RW, Schneider WF, Goralski CT (2006) J Appl Catal B 67:246-256

12. Olsson L, Fridell E (2002) J Catal 210:340-353

13. Mulla SS, Chen N, Cumaranatunge L, Blau GE, Zemlyanov DY, Delgass WN, Epling S, Ribeiro FH (2006) J Catal 241:389-399

14. Yung MM, Holmgreen EM, Ozkan US (2007) J Catal 247: 356-367

15. Irfan MF, Goo JH, Kim SD (2008) Appl Catal B 78:267-274

16. Wang Q, Park SY, Choi JS, Chung JS (2008) Appl Catal B 79:101-107

17. Baerlocher CH, Meier WM, Olson DH (2001) Atlas of Zeolitic Framework Types, Elsevier

18. Olson DH, Kokotailo GT, Charnell JF, Colloid J (1968) Interface Sci 28:305-314

19. Mitsui T, Tsutsui K, Matsui T, Kikuchi R, Eguchi K (2008) Appl Catal B 81:56-63

20. Li LD, Qu LL, Cheng J, Li JJ, Hao ZP (2008) Appl Catal B doi: 10.1016/j.apcatb.2008.09.032

21. Li LD, Zhang FX, Guan NJ, Schreier E, Richter M (2008) Catal Commun 9:1827-1832

22. Bielanski A, Haber J (1979) Catal Rev Sci Eng 19:1-41

23. Xue L, Zhang CB, He H, Teraoka Y (2007) Appl Catal B 75:167174

24. Ji YY, Toops TJ, Graham UM, Jacobs G, Crocker M (2006) Catal Lett 110:29-37 